YAK 347.961.1+(347.626.5:332.22)(477)

DOI https://doi.org/10.32837/chc.v0i37.349

Зінькевич Юлія Євгенівна,

аспірантка кафедри цивільного права

Національного університету "ОАеська юридична академія"

ORCID https://orcid.org/0000-0002-9524-5099

\title{
ПРАКТИЧНІ АСПЕКТИ ПІДГОТОВКИ НОТАРІУСА ДО ПОСВІДЧЕННЯ ДОГОВОРУ ВІДЧУЖЕННЯ СПІЛЬНОГО НЕРУХОМОГО МАЙНА ОДНИМ ІЗ ПОДРУЖЖЯ НА КОРИСТЬ ТРЕТЬОЇ ОСОБИ
}

Постановка проблеми. Сімейне право України закріплює принцип спільності майна подружжя, який означає об'єАнання майна чоловіка і жінки (повністю або у певній частині) в єАину майнову масу та встановлення низки спеціальних правил щоАо його володіння, користування та розпоряАження. За загальним правилом усе майно, яке набуте подружжям за час перебування у шлюбі, $€$ спільною сумісною власністю подружжя. Сенс спільної сумісної власності полягає в тому, що частки співвласників не виділені, а тому кожен з них має рівне право на володіння, користування та розпоряАження цим майном. Чинне законоАавство України надає право на укладення чоловіком і Аружиною Аоговорів віАчуження з іншими особами щодо майна, яке $є$ їх спільною власністю.

Стан АосліАження теми. Питання права спільної сумісної власності поАружжя розглядалися в роботах Аосліаників М.В. Антокольської, В.С. Гопанчука, О.В. Азери, І.В. Жилінкової, О.С. Йоффе, Н.С. Кузнєцової, Р.А. МайАаника, З.В. Ромовської, Є.О. Суханова, С.Я. Фурси, Є.О. Харитонова, Я.Н. Шевченко та інших.

Метою статті $\epsilon$ АосліАження практичних аспектів підготовки нотаріуса Ао посвідчення Аоговорів відчуження нерухомого майна, яке $€$ спільною сумісною власністю поАружжя оАним із поАружжя на користь третьої особи. Необхідність АосліАження цього питання зумовлена потребами нотаріальної спільноти, аАже лише наявність чіткого алгоритму Аій нотаріуса та його Аотримання при піАготовці Ао посвіАчення ВіАповіАних Аого- ворів сприятиме раціональній мінімізації часу вчинення нотаріальної дії та виробленню єАиної нотаріальної практики.

ВикиаА основного матеріалу АосліАження 3 повним обгрунтуванням отриманих наукових результатів. Законодавство України визначає, що Аоговори віАчуження спільного нерухомого майна подружжя оАним із поАружжя на користь третьої особи мають укладатися за їх спільною згодою. В частині 2 статті 65 СКУ сформульована правова презумпція, відповіАно до якої вважається, що ОАин із поАружжя, уклаАаючи Аоговір щоАо спільного майна, Аіє зі ЗгоАи Аругого з поАружжя. Наявність такої згоди може бути оскаржена Аружиною чи чоловіком лише щодо Аоговорів, які виходять за межі дрібного побутового договору. Стосовно Аоговорів, які потребують нотаріального посвідчення і державної реєстрації, згода Аругого з полружжя на їх укладання має бути нотаріально посвідчена.

При посвіАченні Аоговорів віАчуження нерухомого майна, яке $\epsilon$ спільною сумісною власністю подружжя, нотаріус насамперед керується положеннями глави 26 Цивільного кодексу України (право спільної власності), глави 8 Сімейного кодексу України (право спільної сумісної власності поАружжя), положеннями Порядку вчинення нотаріальних дій нотаріусами України, затверАженими наказом Міністерства юстиції України віА 22.02.2012 № 296/5, Правил ведення нотаріального Аіловодства, затвердженого наказом Міністерства юстиції України віА 22.12.2010 № 3253/5, Методичних рекомендацій щодо вчинення 
нотаріальних Аій, пов'язаних із вжиттям захоАів щодо охорони спадкового майна, видачею свідоцтва про право на спаАщину та свідоцтва про право власності на частку у спільному майні подружжя тощо.

Незважаючи на те, що в нотаріальній практиці посвідчення Аосліджуваних Аоговорів $€$ щоденним явищем, вчинення такої нотаріальної дії все ж вимагає сумлінної піАготовки. Першим необхіАним кроком нотаріуса переА посвіАченням Аоговору відчуження спільного нерухомого майна подружжя одним із них на користь третьої особи $€$ встановлення намежності віАчужувачу віАповіАного нерухомого майна на праві спільної сумісної власності, іншими словами - факту набуття нерухомості у період перебування віАчужувача у зареєстрованому шлюбі. Спільною сумісною власністю віАповіАно Ао статті 368 Цивільного кодексу України є спільна власність Авох або більше осіб без визначення часток кожного з них у праві власності.

Майно, набуте подружжям за час шлюбу, $€$ їхньою спільною сумісною власністю, якщо інше не встановлено договором або законом [1]. Згідно зі статтею 60 Сімейного кодексу України майно, набуте подружжям за час шлюбу, належить Аружині та чоловікові на праві спільної сумісної власності незалежно віА того, що один із них не мав із поважної причини (навчання, ведення Аомашнього господарства, Аогляд за Аітьми, хвороба тощо) самостійного заробітку (Аоходу). Вважається, що кожна річ, набута за час шлюбу, крім речей індивідуального користування, є об'єктом права спільної сумісної власності подружжя [2].

Встановлення належності відчужувачу віАповідного нерухомого майна на праві спільної сумісної власності здійснюється на підставі поданих нотаріусу Аокументів, які підтверджують право власності відчужувача на нього. 3 таких Аокументів нотаріус, крім сімейного стану відчужувача на момент посвідчення Аоговору, також визначає час та підставу набуття відчужувачем права власності.

Ао 01.10.2016 з'ясувати сімейний стан особи нотаріус міг і за відміткою, яка проставлялася уповноваженим органом реєстрації актів цивільного стану в паспорті громадянина України. 3 01.10.2016 були введені нові правила реєстрації укладення та розірвання шлюбу, які передбачали скасування обов'язкового проставлення віАміток про сімейний стан у паспорті громадянина України, видачу свідоцтва про укладення / розірвання шлюбу у Авох примірниках, тобто чоло- віку (колишньому чоловіку) та Аружині (колишній Аружині) як єАиного Аокумента, що піАтверАжує сімейний стан особи.

Ці нововведення стали результатом внесення змін до Закону України «Про внесення змін до деяких законів України щодо документів, які підтверАжують громаАянство України, посвідчують особу чи ії спеціальний статус". Натепер вимога законодавця щодо перевірки належності відчужувачу нерухомого майна на праві спільної сумісної власності взагалі не викликає складнощів, оскільки з 01.02.2017 на виконання статті 46-1 Закону України "Про нотаріат" та Наказу Міністерства юстиції України віА 26.12.2016 № 3773/5 «Про затвердження змін Ао Аеяких нормативно-правових актів у сфері державної реєстрації актів цивільного стану" нотаріусам забезпечено можмивість надання безпосереднього Аоступу Ао Аержавного реєстру актів цивільного стану громаАян 3 метою отримання необхінної інформації в межах вчинення нотаріальних Аій шляхом формування відповідних витягів. Так, нотаріус встановлює факт набуття нерухомості, яка буде предметом відчуження в період перебування відчужувача у зареєстрованому шлюбі, шляхом аналізу змісту правовстановлюючого Аокумента на нерухоме майно, що є предметом Аоговору, віАміток у паспорті громаАянина України (в разі їх наявності) та/або відомостей, отриманих шляхом безпосереднього Аоступу Ао Аержавного реєстру актів цивільного стану громаАян.

Аругим кроком нотаріуса при піАготовці $А O$ посвідчення Аоговору відчуження об'єкта спільної сумісної власності подружжя оАним із них на користь третьої особи є з'ясування обставини, хто саме з подружкя звернувся за вчиненням нотаріальної Аії, - особа, на ім'я якої оформлений правовстановлюючий Аокумент на майно, що буде преАметом відчуження (титульний власник), або Аругий із подружжя. З'ясування цієї обставини необхідне Аля визначення подальших Аій нотаріуса.

Нотаріус, встановивши, що за посвіАченням Аоговору віАчуження спімьної нерухомості поАружжя звертається титульний власник, повинен визначити, віА кого саме йому потрібно вимагати письмову згоду на вчинення віАповіАного Аоговору. При вирішенні цього питання необхідним $€$ з'ясування сімейного стану відчужувача як на момент набуття права власності на нерухомість, так і на момент посвідчення відповіАного Аоговору відчуження. На практиці можмиве виникнення таких ситуацій: 
1) на момент набуття права власності та на момент посвіАчення Аоговору віАчужувач нерухомого майна перебував $\boldsymbol{i}$ перебуває у шлюбі з оАнією і тією ж особою;

2) на момент набуття права власності на віАповідне нерухоме майно відчужувач знаходився у шлюбі з оАнією особою, а на момент посвіАчення Аоговору перебуває у шлюбі 3 іншою особою;

3) на момент набуття права власності на віАповідне нерухоме майно відчужувач знаходився у шлюбі з оАнією особою, а на момент посвіАчення Аоговору розлучився з нею та $є$ неодруженим / незаміжньою;

4) на момент набуття права власності на віАповідне нерухоме майно відчужувач знаходився у шлюбі, а на момент посвідчення Аоговору $€$ вАівцем / вАОвою.

Аоцільно розглянути кожну практичну ситуацію окремо та зробити деякі застереження.

Перша ситуація. У випаАку перебування віАчужувача у зареєстрованому шлюбі з однією і тією ж особою як на момент набуття права власності, так і на момент посвідчення Аоговору нотаріус вимагає письмову згоду іншого з подружжя. Справжність підпису Аругого з подружжя на заяві про таку згоду має бути нотаріально засвідчена.

Аруга ситуація. Якщо на момент набуття права власності на відповідне нерухоме майно віАчужувач знаходився у шлюбі з однією особою, а на момент посвідчення Аоговору перебуває у шлюбі з іншою особою, нотаріус вимагає письмову згоду колишнього чоловіка / колишньої Аружини, тобто тієї особи, з ким відчужувач перебував у шлюбі на момент набуття права власності на відчужуване майно.

Третя ситуація. Щодо порядку вчинення нотаріальних дій нотаріусами України (пункт 4.3. глави 1 розділу II) Сімейний кодекс України (ст. 68) переАбачає, що розірвання шлюбу не припиняє права спільної сумісної власності на майно, набуте за час шлюбу [3, 2]. РозпоряАження майном, яке $€$ спільною сумісною власністю, після розірвання шлюбу зАійснюється співвласниками виключно за взаємною згодою віАповіАно Ао Цивільного кодексу України. Це означає, що якщо на момент набуття права власності на віАповідне нерухоме майно відчужувач знаходився у шлюбі з однією особою, а на момент посвіАчення Аоговору розлучився з нею (ним) та є неодруженим / незаміжньою, то нотаріус повинен вимагати письмову згоду колишнього чоловіка / колишньої Аружини відчужувача.
Четверта ситуація. Коли віАчужувач є вАівцем / вАовою, він подає нотаріусу заяву, як це передбачено ПоряАком вчинення нотаріальних Аій нотаріусами України, але у цій заяві, крім зазначення його сімейного стану на момент звернення Ао нотаріуса, має бути зазначено і те, що майно, яке відчужується, не є спільною сумісною власністю подружжя.

Нотаріус Аоводить зміст такої заяви до відома Аругого учасника правочину та зазначає про це в його тексті. Така заява повинна виходити особисто віА відчужувача, а в разі вчинення правочину через представника - віА представника, якщо відчужувач наАав йому право при оформленні правочину подавати віА його імені заяву про належність йому (відчужувачу) майна на праві особистої приватної власності.

Подаючи нотаріусу Аокумент, який посвіАчує право власності на нерухоме майно, що має бути предметом відчуження та з якого видно, що таке майно набуто у спільну сумісну власність, нотаріус не може прийняти таку заяву та посвідчити Аоговір відчуження, оскільки така заява не може містити положення, що майно не $€$ спільною сумісною власністю, без надання Аокументів на підтвердження правового режиму цього майна.

Отже, коли з Аокумента, який посвідчує право власності та інших поданих відчужувачем Аокументів встановлено, що нерухомість набута у шлюбі, то нотаріус не може посвідчити Аоговір відчуження, обмежившись прийняттям заяви віА відчужувача, що він вАова / вАівець. Це пояснюється тим, що віАчужувач у такому випадку не $€$ одноосібним власником майна, яке має бути преАметом Аоговору, бо факт смерті оАного з подружжя не породжує трансформації права спільної сумісної власності у особисту приватну власність того з подружжя, хто пережив іншого. Факт смерті породжує виникнення права на спадкування. Отже, у випаАку смерті одного з подружжя на його частку у праві власності віАкривається спаАщина.

Відповідно до статті 71 Закону України «Про нотаріат" у разі смерті одного з подружжя свіАоцтво про право власності на частку в їх спільному майні видається нотаріусом на підставі письмової заяви Аругого з подружжя з наступним повіАомленням спаАкоємців померлого, які прийняли спаАщину [4]. Порядок видачі свіАоцтва про право власності в разі смерті одного з подружжя Аетально врегульовано розділом 4 частини III Методичних рекомендацій щодо вчинення нотаріальних Аій, пов'язаних із вжиттям заходів 
щодо охорони спадкового майна, видачею свіАоцтва про право на спадщину та свідоцтва про право власності на частку в спільному майні подружжя [5].

Таке свідоцтво може бути видано на половину спільного майна. На підставі письмової заяви спаАкоємців, які прийняли спаАщину, за згодою Аругого з подружжя, який є живим, у свідоцтві про право власності може бути визначена і частка померлого у спільній власності. Свідоцтво про право власності на частку в спільному майні подружжя в разі смерті одного з них видається нотаріусом за місцем віАкриття спаАщини.

Закон не пов'язує можливість отримання свіАоцтва з тим, хто з подружжя звернувся за його отриманням, чи це той із подружжя, на кого оформлений Аокумент, що посвіАчує право власності, чи це той із подружжя, на якого такий Аокумент не оформлений, але спільна сумісна власність Є. Можливість видачі такого свідоцтва закон пов'язує лише з фактом смерті одного з подружжя та визначає, що свідоцтво може бути видане за місцем відкриття спаАщини та в рамках заведеної спадкової справи.

Варто також сказати, що в разі звернення Ао нотаріуса того з подружжя, на кого оформлений Аокумент, що посвіАчує право власності на майно (титульний власник), видача свідоцтва про право власності у спільному майні подружжя не суперечить чинному законодавству. Заява на видачу такого свідоцтва буде підставою заведення спаАкової справи. ПідтверАженням права власності померлого в подружжі буде Аокумент, що посвіАчує право власності на відповідне нерухоме майно, оформлений на заявника. Видача такого свідоцтва $€$ нотаріальним актом, який посвідчує нотаріус в межах наданих йому законом повноважень.

Нотаріус у такому випадку посвідчує факт, який виник раніше на законних підставах, але Ао смерті оАного з подружжя піАтверАжувався іншим Аокументом. 3 видачею цього свідоцтва, а Аалі свідоцтва про право на спаАщину спаАкоємцям померлого із подружжя, первинний Аокумент на майно, що свідчив про набуття майна у період перебування у зареєстрованому шлюбі, залишається у спадковій справі. У того з подружжя, хто пережив, і спадкоємців померлого Аокументами, які підтверАжують право власності, будуть відповіАні свідоцтва про право на спаАщину [6].

Укладення та посвіАчення Аоговорів віАчуження нерухомості, яка є об'єктом спільної сумісної власності подружжя, оАним із подружжя на користь третьої особи в разі звернення Ао нотаріуса того з подружкя, який не зазначений у правовстановлюючому Аокументі на віАчужувану нерухомість, має певні особливості. В такій ситуації необхіАною умовою посвіАчення віАповіАного Аоговору віАчуження спільної нерухомості подружжя є етап трансформації спільної сумісної власності у спільну часткову власність. Як відомо, спільна сумісна власність - це спільна власність Авох або більше осіб без визначення часток кожного з них у праві власності. А^я того, щоб один із учасників спільної сумісної власності мав можмивість розпорядитися належним йому майном, необхідно визначити, що саме йому належить, тобто визначити його частку у праві власності на майно. Без проходження цього етапу не можливо визначити, що саме буде в подальшому перехоАити віА оАного подружжя Ао третьої особи.

Перетворення спільної сумісної власності у спільну часткову власність зАійснюється за Аомовленістю сторін, яка втілюється у Аоговір. У статті 9 Сімейного кодексу України законодавець закріпив право подружжя на укладення між собою сімейних договорів. У статті 7 Сімейного кодексу України йдеться, що сімейні віАносини можуть бути врегульовані, крім Сімейного кодексу, іншими нормативно-правовими актами. Оскільки Сімейним кодексом розширена сфера регулювання сімейних віАносин за Аопомогою Аоговору, то при його укладенні можуть застосовуватися і норми Цивільного кодексу України [2].

Сімейне законодавство передбачає виникнення спільної сумісної власності на майно і рівні права подружжя щодо володіння, користування і розпорядження ним (стаття 63 Сімейного кодексу України). В частині 1 статті 65 Сімейного кодексу України закріплено принцип розпоряАження спільним майном подружжя за взаємною згодою. Статтею 60 Сімейного кодексу України встановлено, що право на майно виникає в обох із подружжя одночасно, у момент набуття його хоча б одним із них, а оформлення права власності на ім'я Аругого з подружжя юридичного значення немає, оскільки майно знаходиться у спільній сумісній власності подружжя без визначення часток.

Частина 1 статті 67, частина 1 статті 70 Сімейного кодексу України передбачають, що правовий режим майна подружжя може бути змінений за Аомовленістю між ними, тобто подружжя має право самостійно визначити розмір часток кожного з них, а також відступити віА засаА рівності часток [2]. Подружжя може визначити 
ілеальні частки в праві спільної сумісної власності, уклавши про це договір. Внаслідок укладення такого Аоговору у кожного з подружжя виникає право на частку у праві спільної часткової власності. ВіАповідно до частини 1 статті 182 та статті 334 Цивільного кодексу України таке право піАлягає державній реєстрації [1]. Відповідно Ао частини 1 статті 2 Закону України «Про державну реєстрацію речових прав на нерухоме майно та їх обтяжень", реєстрація - це офіційне визнання та підтвердження Аержавою фактів набуття, зміни або припинення речових прав на нерухоме майно. Зміна режиму спільної власності піАлягає Аержавній реєстрації, підставою Аля якої $€$ уклаАений договір [7].

Після визначення часток у праві спільної сумісної власності та проведення державної реєстрації відповіАних часток у праві власності кожен із подружжя має право укласти договір відчуження з будь-якою особою. В цьому разі порядок уклаАення та посвідчення договору відчуження належної одному із подружжя частки у праві власності на нерухомість регулюються цивільним законоАавством щодо зАійснення права спільної часткової власності.

Третім кроком нотаріуса при піАготовці Ао посвідчення Аоговору віАчуження об'єкта спільної сумісної власності подружжя оАним із них на користь третьої особи є зАійснення перевірок в єАиних та Аержавних реєстрах Міністерства юстиції України, електронних базах, нормативних переліках. Всі види обов'язкових і факультативних перевірок, які нотаріус зАійснює з метою належної піАготовки до посвідчення Аоговору віАчуження нерухомості, можна умовно поділити на такі групи:

1) перевірка можиивості вчинення нотаріальної дії (перевірка правоздатності та Аієздатності сторін; перевірка місця вчинення правочину; перевірка відсутності малолітніх і неповнолітніх Аітей; перевірка сплати податку перед вчиненням нотаріальної дії тощо);

2) перевірка поданих Аокументів (перевірка ID-паспорта громадянина України; перевірка паспорта громадянина України старого зразка; перевірка податкового номера, перевірка Звіту про оцінку майна; перевірка Аійсності Сертифіката суб'єкта оціночної діяльності; перевірка дійсності Аовіреності; перевірка справжності бланку; перевірка Свідоцтва про шлюб, Свідоцтва про розірвання шлюбу, Свідоцтва про народження, Свідоцтва про смерть у Аержавному реєстрі актів цивільного стану громадян; перевірка Аеклара- ції на сайті ААБІ (Аержархівбудінспекції України) тощо);

3) перевірки віАомостей щоАО об'єкта та суб'єктів Аоговору віАчуження (перевірка відомостей, які містяться в АРРП щоАо нерухомого майна; перевірка відомостей, які містяться в АЗК щодо нерухомого майна, об'єкта незавершеного будівництва; перевірка, чи не змінено назву вулиці, провулку, проспекту тощо внаслідок Аекомунізації; перевірка, чи не $€$ відчужувана нерухомість об'єктом культурної спадщини; перевірка, чи не є об'єкт відчуження проблемним (коли за відомостями ГТУЮ вкрадені, втрачені Аокументи, застереження власників, виявлені піАроблені документи, паспорти тощо); перевірка віАомостей, які містяться в АРРП щоАо віАчужувача / його подружжя; перевірка віАомостей, які містяться в АРРП щоАо набувача / його подружжя; перевірка відсутності податкової застави майна відчужувача та набувача; перевірка, чи є клієнт публічним Аіячем (Аля фінансового моніторингу клієнта); перевірка наявності / відсутності клієнта в переліку осіб, пов'язаних із проваАженням терористичної Аіяльності або щодо яких застосовано міжнародні санкції; перевірка факту застосування санкцій, передбачених статтею 4 Закону України «Про санкції», рішення про застосування яких прийняте Радою національної безпеки і оборони України та введено в Аію указом Президента України, до фізичних або юридичних осіб, які звернулися за вчиненням нотаріальної Аії; перевірка чи не $€$ відчужувач боржником за Ааними ЄАиного реєстру боржників; перевірка, чи не $€$ відчужувач стороною по судовій справі).

Наведений перелік перевірок нотаріуса «зазАалегідь" не $є$ вичерпним. ОАнак, зважаючи на велику кількість перевірок, які повинен зАійснити нотаріус в єАиних та Аержавних реєстрах Міністерства юстиції України, електронних базах, нормативних переліках у процесі піАготовки Ао посвіАчення віАповіАного Аоговору віАчуження, наявність такого загального переліку необхідних перевірок значно полегшує його роботу.

Висновки з АосліАження та перспективи подальших розвідок у цьому напрямі. Незважаючи на те, що в нотаріальній практиці посвідчення Аоговорів віАчуження спільної нерухомості подружжя оАним із подружжя на користь третьої особи є буденним явищем, вчинення такої нотаріальної Аії вимагає віА нотаріуса проведення належної підготовки. Так, першим кроком нотаріуса переА посвідченням Аоговору віАчуження нерухомого майна, що є спільною сумісною власністю подружжя, на 
користь третьої особи є встановлення належності віАчужувачу віАповіАного нерухомого майна на праві спільної сумісної власності, іншими словами факту набуття нерухомості в період перебування у зареєстрованому шлюбі. Аругим кроком піАготовки Ао посвіАчення віАповіАного Аоговору $€$ встановлення, хто саме з подружжя звернувся за вчиненням нотаріальної дії - особа, на ім'я якої оформлений правовстановлюючий Аокумент на майно, що буде преАметом віАчуження (титульний власник), або Аругий із подружжя.

В разі звернення титульного власника нотаріус повинен визначити, віА кого саме вимагати письмову Згоду на вчинення віАповіАного Аоговору віАчуження. При вирішенні цього питання необхідним є встановлення сімейного стану віАчужувача як на момент набуття права власності на нерухомість, так і на момент посвідчення віАповіАного Аоговору відчуження.

В разі звернення Ао нотаріуса того з подружжя, який не зазначений у правовстановлюючому Аокументі на віАчужувану нерухомість, необхіАною умовою посвіАчення віАповіАного Аоговору віАчуження $€$ етап трансформації спільної суміс- ної власності у спільну часткову власність. Перетворення спільної сумісної власності у спільну часткову власність зАійснюється за Аомовленістю сторін, яка втілюється у Аоговір. Зміна режиму спільної власності піАлягає Аержавній реєстрації, підставою Аля якої є укладений Аоговір. Після визначення часток у праві спільної сумісної власності та проведення державної реєстрації відповіАних часток у праві власності кожен із подружжя має право укласти Аоговір відчуження 3 будьякою особою.

Третім кроком нотаріуса при підготовці Ао посвідчення Аоговору віАчуження об'єкта спільної сумісної власності подружжя є зАійснення перевірок в єАиних та Аержавних реєстрах Міністерства юстиції України, електронних базах, нормативних переліках тощо.

Побудова загального алгоритму піАготовчих Аій нотаріуса Аля посвіАчення Аоговору віАчуження спільного нерухомого майна подружжя одним із подружжя на користь третьої особи, а також його Аотримання є запорукою раціональної мінімізації часу вчинення віАповіАної нотаріальної Аії та умовою формування єАиної нотаріальної практики.

\section{NITEPATYPA:}

1. Цивільний кодекс України від 03.10.2003 // Відомості Верховної Ради України. 2003. № 40. С. 356.

2. Сімейний кодекс України від 10.01.2002 № 2947-ІІІ : Закон України // Відомості Верховної Ради України. 2002. Стаття 135.

3. Порядок вчинення нотаріальних дій нотаріусами України : наказ Міністерства юстиції України від 22.02.2012 № 296/5. [Електронний ресурс]. Режим доступу: http://zakon3.rada.gov.ua/laws/show/3425-12.

4. Про нотаріат від 02.09.1993 № 3425-XII : Закон України [Електронний ресурс]. Режим доступу: http://zakon3.rada.gov.ua/ laws/show/3425-12.

5. Методичні рекомендації щодо вчинення нотаріальних дій, пов'язаних із вжиттям заходів щодо охорони спадкового майна, видачею свідоцтва про право на спадщину та свідоцтва про право власності : Рішення Науково-експертної ради з питань нотаріату при Міністерстві юстиції України від 29.01.2009. [Електронний ресурс]. Режим доступу: http://zakon4.rada.gov. ua/laws/show/n0001323-09.

6. Дячук О. Відчуження майна, що є спільною сумісною власністю подружжя, одним із подружжя. [Електронний ресурс]. Режим доступу: http://yurradnik.com.ua/stati/vidchuzhennya-mayna-shho-ye-spilnoyu-sumisnoyu-vlasnistyu-podruzhzhya-odnimiz-nih/.

7. Про державну реєстрацію речових прав на нерухоме майно та їх обтяжень від 01.07.2004 № 1952-IV : Закон України. [Електронний ресурс]. Режим доступу: http://zakon.rada.gov.ua/laws/show/1952-15.

\section{Зінькевич Юлія Євгенівна \\ ПРАКТИЧНІ АСПЕКТИ ПІАГОТОВКИ НОТАРІУСА АО ПОСВІАЧЕННЯ АОГОВОРУ ВІАЧУЖЕННЯ СПІЛЬНОГО НЕРУХОМОГО МАЙНА ОАНИМ ІЗ ПОАРУЖЖЯ НА КОРИСТЬ ТРЕТЬОЇ ОСОБИ}

Стаття присвячена досліАженню практичних аспектів підготовки нотаріуса Ао посвідчення договору відчуження нерухомого майна, яке є спільною сумісною власністю подружжя, одним із них на користь третьої особи. ЗАійснено аналіз норм вітчизняного законодавства, що регулюють питання зАійснення віАчуження спільної нерухомості одним із подружжя на користь третьої особи.

Визначено алгоритм дій нотаріуса при піАготовці до посвідчення Аоговорів відчуження нерухомого майна, яке $€$ спільною сумісною власністю подружжя, на користь третьої особи. Зроблено висновок, що алгоритм підготовчих Аій до посвідчення такого Аоговору відчуження спільної нерухомості подружжя віАрізняється залежно віА того, хто саме з подружжя звернувся до нього за вчиненням нотаріальної Аії, - особа, на ім'я якої оформлений правовстановлюючий документ на майно, що буде предметом відчуження (титульний власник), або Аругий із полружжя.

3'ясовано, що сімейний стан віАчужувача на момент придбання нерухомості та на момент віАчуження віАповіАного нерухомого майна подружжя визначає, віА кого саме нотаріус повинен вимагати віАповіАну заявузгоду на вчинення Аоговору. Узагальнено життєві ситуації, які можуть мати місце у нотаріальній практиці при 
посвідченні Аоговору відчуження спільного нерухомого майна подружжя та визначено віАповіАні заяви, які повинні бути подані нотаріусу при посвідченні такого договору.

Встановлено, що в разі звернення Ао нотаріуса того з подружжя, який не зазначений у правовстановлюючому Аокументі на віАчужувану нерухомість, необхідною умовою посвідчення віАповіАного договору віАчуження є етап трансформації спільної сумісної власності у спільну часткову власність. 3'ясовано, що після визначення часток у праві спільної сумісної власності та проведення Аержавної реєстрації відповідних часток у праві власності кожен із подружжя має право укласти договір відчуження з будь-якою особою.

Киючові слова: спільна сумісна власність, нерухомість, Аоговір відчуження нерухомості, яка $€$ спільною сумісною власністю подружжя, презумпція спільної власності.

\section{Zinkevych Yuliia \\ PRACTICAL ASPECTS OF PREPARATION THE NOTARY FOR JUSTIFYING THE AGREEMENTS OF THE ALIENATION OF JOINT OWNERSHIP BY ONE OF THE SPOUSES IN FAVOUR OF THE THIRD PARTIES}

The article is devoted to the practical aspects of preparation the notary for justifying of the contract on the alienation of the joint ownership of the spouses in favour of the third parties. The analysis of the rules of the domestic legislation on the matters of the alienation of the joint ownership of the spouses in favour of the third parties has been carried out.

An algorithm of proceeding of the notary in preparation for justifying the contracts on the alienation of the joint ownership by one of the spouses in favour of the third parties has been defined. It has been concluded that the algorithm of preparatory actions in order to justify the relevant agreement on the alienation of the joint tenancy of the spouses differ depending on the fact who of the spouses addressed to the notary for implementation of the notary proceeding - the person in whose name the document grant in title on the property is made (the title owner) or the second of the spouses.

It has been ascertained that the marital status of the alienator at the moment of acquiring of the correspondent real estate of the spouses defines the facts from whom of the spouses the notary must demand the relevant claimagreement on implementation of the contract. Life situations which can take place in the notarial practice of justifying the contract on the alienation of the joint tenancy of the spouses and relevant claims which should have been produced to the notary in certifying of such contract have been defined.

It has been determined that in case of approaching a notary by those of the spouses who is not stated in the document grant in title on the alienated property the necessary condition of justifying the relevant contract of alienation is the stage of transformation of the joint tenancy into joint shared ownership. It has been determined that after establishing of the shares in the right of joint tenancy and implementation of the state registration of corresponding shares in the right to property each of the spouses has right to conclude the alienation contract with any person.

Key words: joint ownership, real property, agreement on the alienation of joint ownership, presumption of co-ownership. 